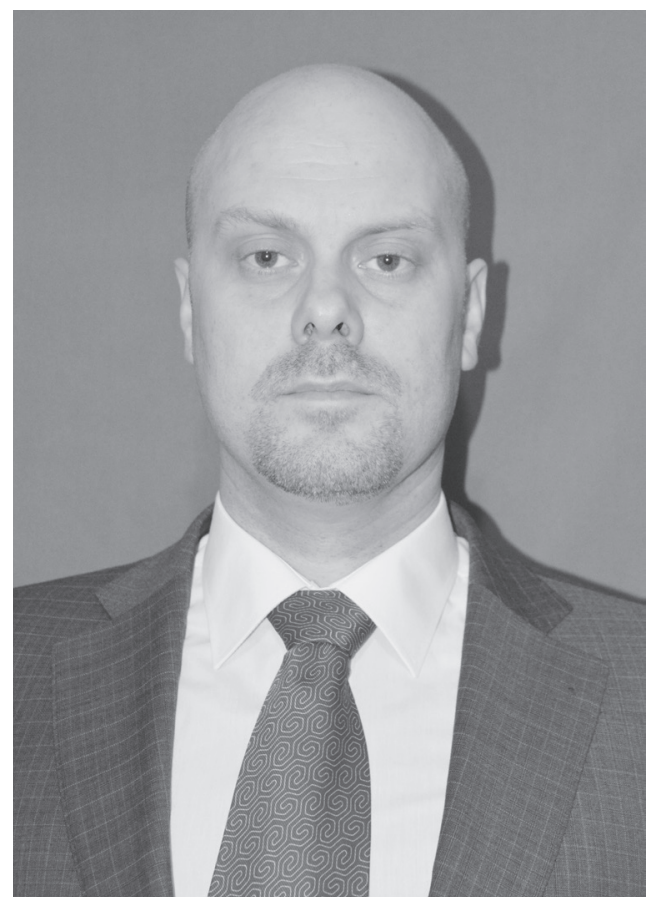

УДК 35::351,354.1;

61::614.2,614.39; 351:614.2.

https://doi.org/10.32689/2617-2224-

2020-5(25)-210-231

Самофалов Дмитро Олександрович, кандидат медичних наук, докторант кафедри гуманітарних та соиіально-політичних наук Одеського регіонального інституту державного управління Начіональної академії державного управління при Президентові Украйни, заступник директора Південного міжрегіонального департаменту Національної служби здоров'я Украйни, 65000, Одеса, вул. Генуезька, 22, тел.: +380506310186, email: Dr.samofalov@gmail.com, https://orcid. org/0000-0001-7850-5365

Самофалов Дмитрий Александрович, кандидат медицинских наук, докторант кафедры гуманитарных и соииально-политических наук Одесского регионального института государственного управления Нащиональной академии государственного управления при Президенте Украины, заместитель директора Южного межрегионального департамента Национальной службы здоровья Украины, 65000, Одесса, ул. Генуэзская, 22, тел.: +380506310186, email: Dr.samofalov@gmail.com, https://orcid.org/0000-0001-7850-5365

Samofalov Dmytro Oleksandrovych,

PhD, Doctoral Candidate of the Humanitarian and Socio-Political Studies Department of the Odessa Regional Institute for Public Administration of the National Academy for Public Administration under the President of Ukraine, Deputy Director of the Southern Transregional Department of the National Health Service of Ukrain, tel: +380506310186, email: Dr.samofalov@gmail.com, https://orcid.org/0000-0001-7850-5365

\title{
ОЦІНКА СТАНУ ТА ЕФЕКТИВНОСТІ ПУБЛІЧНОГО УПРАВЛІННЯ ТА АДМІНІСТРУВАННЯ КОМУНІКАТИВНОЇ ДІЯЛЬНОСТІ ГРОМАДСЬКОГО ЗДОРОВ'я В УКРАї̈І
}

Анотація. Наведено оцінку комунікативної діяльності в публічному управлінні громадським здоров'ям в Україні. Для оцінювання визначені етапи становлення громадського здоров'я в Україні, вивчені відповідні нормативно-правові акти, офіційні вебсайти, надано аналіз розбудови комуніка- 
тивної діяльності громадського здоров'я на різних етапах розвитку. Вивчені основні показники, які можуть бути індикаторами успішності комунікативної діяльності в країні. До таких показників віднесено: фактичні показники здоров’я (кількість інсультів, інфарктів, відмова від шкідливих звичок), комунікативні компоненти, прийняті населенням (виявлення інсульту не медичними працівниками, вуличні реанімації, використання засобів індивідуального захисту, вакцинація) та комунікативні (комунікативні компанії запам'ятовуються населенням, рівень довіри до відправника інформації). Вивчено фактичні показники, та наведено тенденції до змін цих показників за останні п'ять років. Зроблено якісну та кількісну оцінку на основі об'єктивних показників комунікативних компаній та показників здоров'я нації. Визначено, що в Україні тільки починається розбудова інституції громадського здоров'я. Нормативно-правові акти (НПА) недостатні, а стратегія комунікативної діяльності не сформована. Серед комунікативних компаній найбільшу ефективність мала комунікативна діяльність, розроблена за підтримки міжнародних партнерів (ВІЛ, Туберкульоз), та ті, які мають потужні світові тренди (тютюнопаління), однак результати цих компаній також важко вважати задовільними. Визначено, що більшість комунікативних компаній спрямовані на ситуаційну проблему (спалах інфекційних захворювань, вакцинація тощо), при чому повністю відсутня довгострокова комунікаційна стратегія.

Також визначено, що деякі важливі питання громадського здоров’я не були включені та не розглядаються на державному рівні (ожиріння, позалікарняні реанімації тощо).

Ключові слова: публічне адміністрування, охорона здоров'я, комунікативна діяльність, комунікативні технології, комунікації в охороні здоров'я, комунікації в громадському здоров'ї, громадське здоров’я.

\section{ОЦЕНКА СОСТОЯНИЯ И ЭФФЕКТИВНОСТИ ПУБЛИЧНОГО УПРАВЛЕНИЯ И АДМИНИСТРИРОВАНИЯ КОММУНИКАТИВНОЙ ДЕЯТЕЛЬНОСТИ ОБЩЕСТВЕННОГО ЗДОРОВЬЯ В УКРАИНЕ}

Аннотация. Приведена оценка коммуникативной деятельности в публичном управлении общественным здоровьем в Украине. Для оценки определены этапы становления общественного здоровья в Украине, изучены соответвующие нормативно-правовые акты, официальные вебсайты организаций, ответвенных за общественное здоровье, дан анализ становления коммуникативной деятельности общественного здоровья на различных этапах развития. Изучены основные показатели, которые могут быть индикаторами успешности коммуникативной деятельности в стране. К таким показателям отнесены: фактические показатели здоровья (количество инсультов, инфарктов, отказ от вредных привычек), коммуникативные компоненты, приняты населением (выявление инсульта не медицинскими работниками, уличные реанимации, использование средств индивидуальной защиты, вакцинация) 
и коммуникативные (коммуникативные компании, которые запоминаются населением, уровень доверия к отправителю информации). Изучены фактические показатели и приведены тенденции изменений этих показателей за последние пять лет. Сделано качественную и количественную оценку на основе объективных показателей коммуникативных компаний и показателей здоровья нации. Определено, что в Украине только начинается развитие института общественного здоровья. Нормативно-правовые акты (НПА) недостаточны, а стратегия коммуникативной деятельности не сформирована. Среди коммуникативных компаний наибольшую эффективность имела коммуникативная деятельность, разработана при поддержке международных партнеров (ВИЧ, туберкулез), и те, которые имеют мощные мировые тренды (курение), однако результаты этих коммуникационных компаний тоже сложно считать удовлетворительными. Определено, что большинство коммуникационных компаний направлены на ситуационную проблему (вспышка инфекционных заболеваний, вакцинация), при этом долгосрочная коммуникационная стратегия отсутствовала.

Также определено, что некоторые важные вопросы общественного здоровья не были включены и не рассматриваются на государственном уровне (ожирение, внебольничные реанимации и т. д.).

Ключевые слова: публичное администрирование, здравоохранение, коммуникативная деятельность, коммуникативные технологии, коммуникации в здравоохранении, коммуникации в общественном здоровье, общественное здоровье.

\section{ASSESSMENT OF THE STATE AND EFFICIENCY OF THE PUBLIC MANAGEMENT AND ADMINISTRATION OF THE COMMUNICATION ACTIVITY OF PUBLIC HEALTH IN UKRAINE}

Abstract. An assessment of communication activity in the public management of public health in Ukraine is given. To assess the stages of formation of public health in Ukraine, the relevant normative legal acts, official websites, analysis of the development of communication activities of public health at different stages of development are defined. The main indicators that can be indicators of the success of communication activities in the country are studied. Such indicators include: actual health indicators (number of strokes, heart attacks, the abandonment of bad habits), communication components accepted by the population (detection of stroke by non-medical workers, street resuscitation, use of personal protective equipment, vaccination) and communication (communication companies are remembered by the population, the level of trust in the sender of information). The actual indicators are studied, and the tendencies to changes of these indicators for the last five years are given. A qualitative and quantitative assessment was made on the basis of objective indicators of communication companies and indicators of the nation's health. It has been determined that the development of the public health institution is just beginning in Ukraine. Norma- 
tive legal acts (NLA) are insufficient, and the strategy of communication activity is not formed. Among communication companies, communication activities developed with the support of international partners (HIV, Tuberculosis) and those with strong global trends (smoking) were the most effective, but the results of these companies are also difficult to consider satisfactory. It is also determined that most communication companies focus on the situational problem (outbreak of infectious diseases, vaccination, etc.) and there is no long-term communication strategy.

It is also determined that some important public health issues have not been included and are not addressed at the state level (obesity, outpatient intensive care, etc.).

Keywords: public administration, healthcare, communication activities, communication technologies, healthcare communications, public health communications, public health.

Постановка проблеми. Сьогодні, в українській медичній галузі можна спостерігати досить бурхливий розвиток нового напряму - громадське здоров'я (Public health). Відповідно до визначення Всесвітньої організації охорони здоров'я (ВООЗ), громадське здоров'я виступає серед ключових компонентів системи охорони здоров'я, яка функціонує належним чином. Серед головних завдань громадського здоров'я в першу чергу визначено покращення стану здоров'я кожного громадянина та популяції в цілому, профілактика захворювань, збільшення тривалості життя та подовження активного періоду шляхом організованих зусиль суспільства [1].

Світовий досвід вказує, що в комунікативній діяльності громадського здоров'я основною повинна стати розробка політик і стратегій, спрямованих на профілактику хвороб, протиепідемічні заходи, охорону та промоцію здоров'я. Для успішного впровадження такої моделі уряд по- винен вести комунікації з широким колом стейкхолдерів. Така позиція цілком відповідає системному підходу [2;3].

Не дивлячись на те, що оцінка комунікативної діяльності досить важлива для розуміння стану громадського здоров'я, визначити ключові компоненти для оцінки дуже складHO.

Україна розпочала розбудову громадського здоров'я менше десяти років тому і сьогодні в системі все ще спостерігається "первісний хаос", отже, важливо із самого початку зрозуміти рівень та якість наявної комунікаційної діяльності та зробити необхідні кроки для стратегічної розбудови цього вкрай важливого напряму, враховуючи ролі усіх зацікавлених сторін.

Аналіз останніх досліджень і публікацій. Для українського наукового простору термін "громадське здоров'я" (Public health) досить новий та має багато різних трактувань, однак у більшості випадків він відобра- 
жає якісно новий підхід до розвитку сфери охорони здоров'я. Серед вітчизняних наукових розробок погляд на трактування терміна та на роль громадського здоров'я (Public health) висвітлені в роботах I. С. Миронюка, Г. О. Слабкого, О. О. Кюкало $[4 ; 5]$.

Серед важливих робіт, в яких вивчається громадське здоров'я, слід зазначити М. М. Белінську, яка даючи оцінку впливу публічного управління на розвиток громадського здоров'я в Україні, торкається виключно питань економіки та добробуту, і водночас, не розглядаючи комунікативної складової. Відповідно не проводиться оцінка ефективності розвитку цієї галузі в Україні [6].

$\mathrm{y}$ роботах T. А. Занфірової та Я. Ф. Радиша визначенна багатокомпонентність сфери громадського здоров'я, однак не відображено такі важливі складові, як публічна та комунікативна, відповідно і немає оцінки успішності або ефективності [7].

К. О. Булавіновою, О. З. Децик та 3. О. Цихонь надано ретельний аналіз ролі комунікативних стратегій, розглянута етапність розвитку та визначені деякі важливі точки розвитку комунікативної діяльності сфери громадського здоров'я в Україні, однак не проведено оцінки якості комунікативної діяльності [8].

Мета статті. Вивчити модель комунікативної діяльності у сфеpi громадського здоров'я в Україні, яка існує на даний час. Визначити об'єктивні критерії оцінки, засновані на доказах, та провести оцінку комунікативної моделі, яка є наявною в Україні. На основі аналізу результатів запропоновати шляхи покра- щення моделі публічного управління та адміністрування комунікативної діяльності громадського здоров'я в Україні.

Виклад основного матеріалу дослідження. Насамперед, оцінку комунікативної діяльності доцільно розглядати, виходячи 3 чіткого визначення моделі такої діяльності, притаманній нашій країні. У сучасній науковій літературі досі не існує узагальненого визначення поняття "модель", однак частіше під терміном "модель” розуміють систему або лінії побудови взаємодії за допомогою спілкування, діалогу, інформування або обміну адміністративною інформацією [2]. У різних країнах застосовують або адміністративну лінійно-функціональну модель побудови комунікації, спрямовану на обмін інформацією в системі адміністративних відносин. Така модель передбачає лише інформування громадськості про ситуацію. Відповідно до моделі очікується, що громадяни мають все зрозуміти і поводитись визначеним чином. Майже протележну модель використовують більшість демократичних країн - вербалізація нового публічного менеджменту та гарного, або належного менеджменту, в основі яких лежить перенесення всієї відповідальності за результати комунікації на цільову групу, якою виступає громадськість. Ця модель грунтується на ідеї активної участі населення у вирішенні всіх проблем держави. У цій моделі громадськість виступає вже не об'єктом інформування, а повноправним суб'єктом комунікативної діяльності та бере на себе відповідальність за власне здоров'я. 
В Україні розвиток громадського здоров'я знаходиться на ранніх стадіях, однак вже чітко можна визначити три основні етапи.

Перший етап розвитку - розбудова вертикалі управління системи громадського здоров'я в Україні розпочався при приєднанні України як члена $\mathrm{OOH}$ та підписанта угоди про асоціацію між Україною та Європейським Союзом, Європейським співтовариством з атомної енергетики, до реалізації Цілей сталого розвитку через розробку відповідних національних стратегічних завдань. Цей документ у Главі 22 визначав зобов'язання України щодо впровадження заходів для захисту здоров'я людини як передумови сталого розвитку й економічного зростання.

Була створена інституція для координації всіх залученних акторів цього процесу (системи охорони здоров'я, інших міністерств та відомств, органів місцевого самоврядування, громадських та пацієнтских організацій, та самих громадян) - Державна установа "Центр громадського здоров’я МОЗ України” (ДУ “ЦГЗ МОЗ України”). У листопаді 2016 р. Кабінет Міністрів України схвалив Концепцію розвитку системи громадського здоров'я, а в 2017 р. Розпорядженням КМУ було затверджено план заходів щодо реалізації Концепції розвитку системи громадського здоров'я.

На другому етапі формування комунікативної діяльності була представлена реформа системи громадського здоров'я для всіх рівнів національного, регіонального та місцевого. Важливим питанням були комунікації директорату громадсько- го здоров'я та ЦГЗ з іншими міністерствами. Для впровадження політики та відповідної комунікації були створені регіональні ЦГЗ, які об'єднали Центри медичної статистики, Центри здоров’я, Центри моніторингу та оцінки виконання програмних заходів з протидії ВІЛ-інфекції/СНІДу та туберкульозу (Центр МiO), лабораторні центри МОЗ [9].

Слід зазначити, що а ні в наведеній стратегії, а ні в подальшому не було визначено чітких критеріїв та індикаторів ефективності як комунікативної діяльності, так і в цілому діяльності регіональних ЦГЗ. Як можна спостерігати, їх комунікативна діяльність спрямована або на ситуативну проблему (вакцінація, спалах інфекційних захворювань), або торкаючись значущих питань здоров'я (ВІЛ, вживання алкоголю, профілактика онкологічних захворювань) не враховує державні та місцеві програми інших установ, що існують паралельно.

На третьому етапі нарешті було поставлено питання недостатньої кількості фахівців у галузі та підготовки медичних фахівців стосовно комунікативної діяльності щодо проблем громадського здоров'я. Важливим кроком стало створення бакалаврської програми по "громадському здоров”ю”, що втілюються як на новостворених кафедрах громадського здоров'я (Ужгородський національний університет, НМАПО ім. П. Л. Щупика тощо), так і на кафедрах соціальної медицини, організації охорони здоров'я та медичного правознавства (Івано-Франківський національний медичний університет). А також розширення 
магістерських програм для забезпечення потреб у здобутті комунікаційних та загальних компетенцій в громадському здоров'ї керівників закладів охорони здоров'я. Створені освітні програми за спеціальністю “громадське здоров'я”. Також на третьому етапі відмічена висока активізація різних тренінгів та шкіл 3 комунікації, пов'язаної з питаннями громадського здоров'я. Або як зазначає К. О. Булавінова, в Україні ця робота проводиться на волонтерських засадах, приватними тренінговими центрами або за кошти міжнародних організацій та жодним чином не пов'язана із системним баченням державної стратегії щодо комунікативної діяльності громадського здоров'я [8].

У науковій літературі методи та підходи оцінки комунікативної діяльності спрямовані виключно на комунікативну діяльність у комерційній сфері. У більшості публікацій визначають дві групи параметрів, що дають змогу оцінити зростання продажів та вплив їх на особистість. Однак такий підхід не є задовільним для оцінювання ефективності комунікаційної діяльності в громадському здоров'ї. Адже необхідно використовувати об’єктивні показники, які виходять із цілей та напрямів громадського здоров'я загалом [10; 11].

Отже, доцільно вивчати показники, які вказують як на поліпшення здоров’я громади в цілому, так і на результати самих комунікативних компаній: фактичні показники здоров'я (кількість інсультів, інфарктів, відмова від шкідливих звичок), комунікативні компоненти, прийняті населенням (виявлення інсульту не медичними працівниками, вуличні реанімації, використання засобів індивідуального захисту, вакцинація) та комунікативні (комунікативні компанії запам'ятовуються населенням, рівень довіри до відправника інформації).

Виходячи 3 аналізу офіційного сайту ДУ “ЦГЗ МОЗ України” (www. phc.org.ua), можна зазначити, що інституція у співпраці з міжнародними партнерами реалізує чисельні проєкти, спрямовані в першу чергу на протидію ВІЛ-інфекції/СНІДу, туберкульозу. Серед проєктів зазначено: Посилення спроможності лікування ВІЛ/СНІД в Україні в рамках Надзвичайної ініціативи Президента США з надання допомоги у боротьбі з ВІЛ/СНІД (PEPFAR); Підтримка системи епідеміологічного нагляду за ВІЛ і системи управління/поліпшення якості лабораторій Міністерства охорони здоров'я України, покращення використання стратегічної інформації та розбудова потенціалу громадської охорони здоров'я в рамках Надзвичайної ініціативи Президента США з надання допомоги у боротьбі з ВІЛ/СНІД (PEPFAR); Прискорення прогресу України в забезпеченні сталої відповіді сфери охорони здоров'я на туберкульоз і ВІЛ-інфекцію; Надання підтримки Україні в розвитку сучасної системи громадського здоров'я; FHI Співпраця з Україною у сфері охорони здоров'я; Посилення реалізації Рамкової конвенції ВООЗ із боротьби проти тютюну в Україні.

У межах цих проектів визначено поодинокі комунікативні складові: оптимізація та адвокація антіретровірусної терапії (АРТ), удосконалення 
інформаційних систем з імунізації, підвищення обізнаності регіональних ЗМІ у темі контролю над тютюном. У той же час жоден з проектів не містить багаторівневої національної стратегії комунікаційної діяльності. Крім того, багато питань громадьского здоров'я, які в усьому світі виступають індикаторами (ожиріння, інсульт, інфаркт, психічне здоров'я), не знайшли відображення на офіційному сайті ДУ “ЦГЗ МОЗ України”.

Що стосується регіональних підрозділів, то серед цілій та місій визначена освітня діяльність і соціальна комунікація, адаптовані до потреб конкретних соціально-економічних груп і покликані сприяти оздоровленню способу життя і поведінки населення, навколишнього середовища [12]. При цьому самі центри в Інтернеті представлені слабо, багато 3 них не мають навіть відокремленого від Департаменту охорони здоров'я веб-сайту. Що стосується комунікативних інструментів, здебільшого використовують соціальні мережі, найчастіше Facebook, матеріали на сторінках розташовані хаотично та фрагментарно, здебільшого власний контент відсутній. Одеський обласний ЦГЗ випускає електронний журнал "Медичний простір”, випуски якого розташовані на їх власному сайті (https://healthcenter.od.ua/ online/zhurnal-medychnyj-prostir/). Сам по собі журнал виступає більше в якості інформаційного бюлетеню.

Найширше в Україні представлена комунікативна діяльність щодо поширеності ВІЛ-інфекції/СНІДу і факторів, які сприяють іï розвитку. Слід зазначити, що в Україні досить досконало представлені усі теми, пов'язані з поширеністю ВІЛ-інфекції/СНІДу - від профілактики до адвокації АРТ та запобіганню стигматизації цих верств населення. У межах публічного управління прийнято ряд нормативно-правових актів (НПА) (Закон України "Про протидію поширенню хвороб, зумовлених вірусом імунодефіциту людини (ВІЛ), та правовий і соціальний захист людей, які живуть з ВІЛ”, Розпорядження КМУ "Про схвалення Стратегії забезпечення сталої відповіді на епідемії туберкульозу, в тому числі хіміорезистентного, та ВІЛ-інфекції/СНІДу на період до 2020 року та затвердження плану заходів щодо їі реалізації, накази МОЗ “Про внесення змін до Переліку захворювань, за наявності яких особа не може бути усиновлювачем", "Про затвердження Методичних рекомендацій щодо надання правової допомоги жінкам із вразливих соціальних груп”, "Про затвердження Порядку надання послуг з профілактики ВІЛ серед представників груп підвищеного ризику щодо інфікування ВІЛ”, Про затвердження Змін до Типового положення про кабінет "Довіра") внесення до Програми медичних гарантій: лікування пацієнтів з ВІЛ-інфекцією, та визначення, що АРТ препарати в Україні є доступними для кожної людини 3 ВІЛ-інфекцією та надаються також безоплатно.

Відповідно до зазначених НПА розроблено стратегію, яка включає і комунікативну діяльність громадського здоров'я щодо основних напрямів: профілкатика ВІЛ/СНІДу серед населення України, використання засобів індивідуального захисту, особливо серед підлітків та 
соціально невідповідальних верств населення, тестування на ВІЛ-інфекцію, адвокацію АРТ-терапії, запобігання стигматизації людей, які живуть з ВІЛ (ЛЖВ).

За останні роки проведені числені комунікативні кампанії, спрямовані на профілкатику, запобігання, виявлення ВІЛ/СНІДу, адвокації АРТ та запобігання стигматизації ЛЖВ, за участю ДУ “ЦГЗ МОЗ України”, регіональних центрів ЦГЗ, Міжнародних організацій (BOO3, UNICEF, USAID та ін.) та ГО ("100 \% життя", “Альянс громадського здоров’я”, БО "Позитивні жінки”, ХМГО "21 століття” тощо).

За оцінкою ВООЗ, Україна є регіоном з високим рівнем поширення ВІЛ-інфекції. Відповідно до даних ДУ “ЦГЗ МОЗ України” та оцінкою UNAIDS, кількість ЛЖВ в Україні досягає 240 тис. осіб. Лише кожна друга ВІЛ-позитивна людина знає про свій статус і звертається по медичну допомогу. У той же час за твердженням М. О. Андрущак та співавторів, 75 \% ВІЛ-позитивних людей у світі знали про свій ВІЛ статус (70 \% на початку 2017 р.); 79 \% тих, хто знав про свій ВІЛ-статус, отримували лікування, 81 \% тих, хто отримував АРТ, досягли невизначеного рівня вірусного навантаження на ВІЛ у крові [13]. Станом на 1 травня 2019 р. на обліку в Україні перебуває 143766 ЛЖВ [14], зберігається негативна тенденція до пізнього виявлення ВІЛ, який діагностується у більше, ніж половини осіб у 3- та 4-й клінічних стадіях [15].

Аналізуючи ситуацію щодо негативної тенденції в протидії ВІЛ в Україні, С. М. Шапка зазначає, що держава проводить виключно політику щодо адвокації АРТ, не приділяючи уваги іншим аспектам, направленим на зменшення кількості інфікування ВІЛ в Україні [16], що на думку А. Горпинич, незважаючи на велику увагу, направленої на питання дискримінації та стигми ВІЛ позитивних осіб, ці явища залишаються широко розповсюдженими серед нашого суспільства [17], а В. В. Огоренко та О. М. Гненна вказують на нетолерантне ставлення до ЛЖВ, навіть у 17,7 \% студентів VI курсу медичних університетів [18].

Вивчаючи фактичні показники здоров'я, доцільно зосередитись на тих, які виступають основними факторами смерті та інвалідізації, та на які найбільше впливає комунікація громадського здоров'я: ожиріння, стан допомоги при інсультах, захворюваннях системи кровообігу, відмова від шкідливих звичок.

Україна посідає 14 місце серед європейських країн за кількістю людей 3 ожирінням (на ожиріння страждає 22,1 \% населення). Для порівняння, у Великобританії цей показник становить 28,4 \% для жінок та 26,2 \% для чоловіків, і є найгіршим у Європі [19]. Не дивлячись на те, що зараз спостерігається світовий тренд щодо подолання ожиріння, а комунікації з цього приводу проводяться як медичними, так і не медичними фахівцями (фітнес-інструкторами, інфлюенсерами, інстаграм-моделями), в Україні не існує широких комунікативних компаній щодо цієї проблеми. Єдиним заходом, направленим на громадськість, є розроблена МО3 в співпраці з “Асоціацією дієтологів України” тарілка здорово- 
го харчування українця [20]. Однак і ця ініциатива не знайшла широкого відображення в інформаційному полі.

Що стосується дитячого ожиріння, то відповідно до даних Державного закладу "Центр медичної статистики МО3” показник поширеності ожиріння серед дитячого населення України значно нижчий порівняно з країнами Європи (http:// medstat.gov.ua/ukr/statdan.html). Однак на думку I. Е. Заболотна та Л.В. Ященко, це пов'язано не з кращим станом громадського здоров'я та профілактичної медицини, а 3 тим, що вивчення та статистичний аналіз поширеності надмірної маси тіла серед дитячого населення України не проводиться [21]. На думку К. Г. Помогайбо, пацієнти дитячого віку вперше звертаються за медичною допомогою з приводу скарг, пов'язаних з розвитком ускладнень ожиріння [22]. Ще одним важливим показником є те, що за даними ВООЗ у 2001 р. в Україні кількість дітей із зайвою вагою була 14,4%. Це вказує, що система профілактики ожиріння у дітей має ряд недоліків в організації, процесі та результатах: недотримання лікарями первинної ланки надання медичної допомоги дитячому населенню, нехтуванням чинних протоколів, відсутністю та фрагментарністю нормативно-правової бази, відсутністю узгодженості між нормативними документами $\mathrm{Mi-}$ ністерства охорони здоров'я та відсутністю документів, які визначають стратегію комунікативної діяльності в цьому питанні.

У більшості країн світу основними викликами громадського здоров'я стали неінфекційні захворювання, що призводять до інвалідізації та смерті: травми, інсульти, інфаркти. За офіційною статистикою, в Україні цереброваскулярні захворювання $\mathrm{\epsilon}$ другими серед усіх причин смертності (100000-110000 смертей, близько 14 \% усіх померлих). Однак слід зазначити, що частота смертей від цих захворювань більшою мірою обумовлена якістю та доступністю спеціалізованої медичної допомоги. Отже не може виступати чітким показником ефективності громадського здоров'я, а скоріше вказує на ефективність, чи не ефективність системи охорони здоров'я в цілому.

Досить показовим щодо оцінки результативності комунікаційної діяльності громадського здоров'я виступає інсульт.

Адже це захворювання має чіткі фактори ризику: високий артеріальний тиск, малорухливий спосіб життя, наявність шкідливих звичок (куріння і надмірне вживання алкоголю), високий рівень холестерину в крові, ожиріння і діабет, на які можна впливати через комунікаційну діяльність, спрямовану на зміну способу життя.

Крім того дуже важливим щодо інвалідізації є раннє виявлення інсульту та відповідне лікування. Щодо раннього виявлення інсульту в Сполучених Шататх Америки та в країнах Європейського Союзу проводяться інформаційно-комунікативні програми, направлені на раннє виявлення інсульту не медичними працівниками. Лозунгом цих програм виступає - "Мозок це час". За рахунок раннього виявлення інсульту та доступності кваліфікованої 
медичної допомоги в країнах Європи та в США до 80 \% тих, хто переніс інсульт, повертається до нормального способу життя.

Щороку стається 100000-110000 інсультів (понад третина з них - у людей працездатного віку), а за даними Української асоціації боротьби з інсультом реальна цифра сягає 150000. 30-40 \% хворих на інсульт помирають упродовж перших 30 днів і до $50 \%$ - протягом року від початку захворювання; 20-40 \% хворих, що вижили, стають залежними від сторонньої допомоги (12,5 \% первинної інвалідності) і лише близько 10 \% повертаються до повноцінного життя [23]. Дослідження, проведене в південному регіоні показало, що до 2015 р. 25-30 \% серед усіх викликів екстреної медичної допомоги з приводу інсульту хворі відмовлялися від госпіталізації. Причини відмови здебільшого були пов'язані з поганою інформованостью хворого та його родичів щодо сучасних стандартів лікуватися інсульту (13,5 \%), та наявністю серед родичів лікарів або середніх медичних працівників $(11,7 \%)$, браком коштів $(18,9 \%)$, сімейними обставинами (6,3\%), загальним тяжким станом хворого (4,5\%). За останні два роки кількість відмов від госпіталізації за наявності інсульту зменшилася у 2,5 раза, також зросла на 36,3 \% кількість пацієнтів, яких доставили до лікарні в рамках терапевтичного вікна [24].

Однак позитивні зміни скоріш пов'язані з покращенням доступності допомоги при інсульті та комунікаціями, які проводить Національна служба здоров'я України (НСЗУ). 3 2020 р. лікування гострого мозкового інсульту включено як пріоритет до Програми медичних гарантій. Відповідно НСЗУ, як відправник інформації, проводить постійні комунікаційні кампанії щодо доступності та безоплатності такої допомоги [25]. Водночас комунікації, які стосуються суто громадського здоров'я при інсульті (вміння впізнати ознаки інсульту, допомога хворим у реабілітації, створення доступного середовища) в Україні проводяться громадськими організаціями (ГО "Українська асоціація боротьби з інсультом”, ГО "Південноукраїнська регіональна асоціація ангіоневрології”) та міжнародними організаціями Свропейська організація інсульту (European Stroke Organisation), Свропейській проект "Ініціатива Angels" (Angels Initiative) [26]. Один з небагатьох відеороликів, в якому навчають виявляти ознаки інсульту, був створений Полтавським інсультним симуляційним центром за підтримки Свропейського проекту "Ініціатива Angels" (Angels Initiative).

Що стосується комунікацій щодо профілактики серцево-судинних захворювань, спостерігається приблизно така сама ситуація. Інфаркт міокарда віднесен ВООЗ до найважливіших неінфекційних захворювань. За даними I. I. Кошеля, в останні роки в Україні спостерігається зниження показника захворюваності населення на гострий інфаркт міокарда з рівнем у 117,2 на 100 тис. дорослого населення, визначається деяке коливання в розрізі адміністративних територій, яке становить 1,55 раза. Визначаються гендерні особливості інфаркту серед чоловіків показник захворюваності на гострий 
інфаркт міокарда $(153,3)$ у 1,75 раза вищий, ніж у жінок $(87,5)$, що відповідає загальносвітовій тенденції [27]. Крім того, в останні роки спостерігається тенденція до зменшення показника смертності населення України внаслідок інфаркту міокарда, що зумовленно не розбудовою комунікативної стратегії, спрямованої на попередження розвитку самого захворювання, а на розбудову мережі Реперфузійних центрів, які працюють у режимі 24 години 7 днів на тиждень, 365 днів на рік (24/7/365). 3 цими центрами НСЗУ уклало договори щодо надання допомоги населенню України за Програмою медичних гарантій. Також НСЗУ проводить відповідні комунікаційні кампанії щодо можливості та прав пацієнта на отримання медичної допомоги у цьому напрямі [28]. Крім того, за даними К. Сокол, в Україні від ГІМ (близько 50 тис. хворих) щорічно помирає $20 \%$ пацієнтів, тоді як в країнах Європи - 5 \% [29], а відповідно до математичної моделі В. В. Рудень, I. М. Ковальська [30] спостерігається тенденція до зростання, що свідчить про неефективність наявних стратегій комунікативної та превентивної діяльності, направленої на це захворювання.

Відповідно до наявних програм ДУ “ЦГЗ МОЗ України” основні комунікативні кампанії спрямовані на відмову від шкідливих звичок та впровадження безпечного способу життя (профілактика ТБ, ВІЛ тощо).

Відповідно до інформації ДУ “Центр громадського здоров'я МОЗ” в Україні 85000 смертей щороку пов'язані власне із курінням, і понад $14000-3$ впливом вторинного тю- тюнового диму. У 2019 р. стартувала національна інформаційна кампанія “тютюновий дим - невидимий вбивця”, у виданому звіті зазначено, що завдяки успішній адвокаційній кампанії, яка тривала у 2017-2019 pр. у січні 2020 р. було ухвалено низку законодавчих актів, які з 2021 р. втричі підвищать акциз на тютюнові вироби електричного нагрівання, сигарили та впроваджують податок на електронні сигарети. Також зареєстровано законопроєкт 2813, який збільшує кількість громадських місць, у яких буде повністю заборонено куріння.

Слід зазначити, що це перша національна інформаційно-комунікаційна кампанія, спрямована на боротьбу з тютюном. У кампанії залучені 25 національних та понад 60 регіональних телеканалах, на яких транслюють соціальний відеоролик про шкоду від пасивного куріння. Крім того в столиці та 10 містах України на вулицях розташована соціальна реклама. Включення регіональних центрів громадського здоров'я дало можливість розповсюдити понад 10000 постерів, 25000 наклейок та листівок про загрози пасивного куріння, насамперед для дітей, які не можуть себе захистити самостійно.

Сьогодні рано оцінювати успішність національної антитютюнової кампанії, однак можна зазанчити, що загалом у 2008-2019 рр. реалізація сигарет в Україні скоротилася з 125 млрд до 45 млрд сигарет, тобто на 80 млрд або $64 \%$. Крім того зазначено, що запуск антитютюнової кампанії привів до більшої залученості громадян, які захищають право на бездимне середовище. Проведене до- 
слідження визначає, що серед респондентів на 3,2 \% більше стали робити зауваження курцям у невідповідних місцях (21 \% до 24,2 \% після початку кампанії), на 1,3 \% громадян наклеїли знак "Куріння заборонено" (2,2% та 3,5 \% відповідно) та на 1,2 \% більше поскаржилися до відповідних органів (2,1 \% та 3,3 \% відповідно) [31].

Важливим індикатором успішних комунікаційних кампаній громадського здоров'я можна вважати зміну способу життя відповідно до комунікативних кампаній (виявлення інсульту не медичними працівниками, вуличні реанімації, використання засобів індивідуального захисту, вакцинація) та комунікативні (комунікативні кампанії запам'ятовуються населенням, рівень довіри до відправника інформації).

Відповідно до світової статистики більшість зупинок серця в наслідок захворювань, не пов'язаних з травмою, стаються на вулиці, поза досяжністю медичного персоналу. Таким чином, Audrey L Blewer та співавтори вказують на частоту позалікарняних серцево-легеневих реанімацій як важливу складову громадського здоров’я. Відповідно до даних Американської асоціації серця (American heart association (AНA)) серцево-легенева реанімація (СЛР) не медичних працівників підвищує шанс людини вижити внаслідок зупинки серця поза лікарнею, однак частота таких СЛР у більшості країн низька (приблизно 40 \%) [32].

Не дивлячись на високу зацікавленість громадськості у навчанні 3 домедичної допомоги, що зумовлено подіями з великою кількістю людських жертв та інвалідізацій впродовж останніх п'яти років. Революція Гідності, антитерористична операція на Сході країни, нестабільна суспільно-політична ситуація із сутичками та протистояннями, велика кількість надзвичайних ситуацій, ДТП та терористичні акти. Важливо зазначити, що у 2007 р. було створено Державний заклад "Український науково-практичний центр екстреної медичної допомоги та медицини катастроф МОЗ України", а в 2014 р. МО3 України затвердив порядки надання домедичної допомоги особам при невідкладних станах (Наказ МОЗ України від 16.06.2014 р. № 398). Крім того, ДЗ “Український науково-практичний центр екстреної медичної допомоги та медицини катастроф МОЗ України” визначено головною установою, що надає організаційно-методичну допомогу та здійснює науковий супровід заходів щодо створення та функціонування єдиної системи екстреної медичної допомоги, який зазначає, що інституція повинна розробляти та впроваджувати комунікативну діяльність щодо домедичної допомоги. У 2013 р. заклад пройшов державну акредитацію та внесений до Державного реєстру наукових установ, яким надається підтримка держави. Однак, слід зазначити, що а ні дЗ "Український науково-практичний центр екстреної медичної допомоги та медицини катастроф МОЗ України”, а ні ДУ “ЦГЗ МОЗ України" не проводить ніякої комунікативної діяльності щодо підготовки немедичних працівників щодо домедичної допомоги.

Сьогодні в Україні діє велика кількість приватних закладів, які 
проводять курси та майстер-класи щодо домедичної допомоги, однак а ні єдиного стандарту навчання, а ні якихось заходів щодо акредетації курсів в Україні не існує. Так різні приватні тренінгові центри навчають за різними програмами. Так, ВГО “Всеукраїнська рада реанімації та екстреної медичної допомоги” навчає відповідно до стандартів Європейської ради ресусцитації (European Resuscitation Council, ERC), та виступає представником України в мережі національних рад ресусцитації у Європі. ТОВ “Центр спеціальної підготовки” навчає відповідно до стандартів Американської асоціації серця (American Heart Association (AHA)). Ще одним важливим актором щодо навчання домедичної допомоги виступає Товариство Червоного Хреста України, програми якого сертифіковані в референс-центр із першої допомоги Міжнародної Федерації Товариства Червоного Хреста та Червоного Півмісяця. Водночас більшість організацій, що проводять навчання немедичних працівників в Україні (Учбовий центр SAR ®, "Курси першої домедичної допомоги “САВ”, 44 Навчальний Центр та ін.), проводять навчання за власними програмами, які жодним чином не перевіряються та не узгоджені з існуючими в Україні НПА. Усі ці організації займаються комунікативною діяльністю, здебільшого спрямованою на комерційні потреби та створення попиту серед населення щодо знань з домедичної допомоги. Така комунікативна діяльність також не є узгодженою, та навряд чи дає системний результат. Так, за даними Українського фонду “Здоров’я” 82 \% рес- пондентів відповіли, що не зможуть надати першу невідкладну медичну допомогу постраждалому, адже не знають, що робити. Ще 62 \% не стануть рятувати, бо бояться нашкодити та можливої відповідальності, яка може наступити внаслідок таких дій. Також відповідно до дослідження тільки 1 \% вміє користуватися автоматичним зовнішнім дефібрилятором, в той час як в Свропі цей показник становить $40 \%$.

Глобальною проблемою комунікацій громадського здоров'я виступає вакцинація. Охоплення вакцинацією проти дифтерії, кашлюку та правця є хорошим маркером успішності програм імунізації в країні. Усі країни високим доходом мають рівень охоплення щепленнями понад 90 \%. Виходячи 3 досліджень, правильно побудовані комунікативні стратегії дають кращий результат, ніж законодавчі примуси та заборони. Відмічається збільшення кількості батьків, які вважають, що обов’язкова вакцинація порушує їх громадянські права, що призводить до явного зниження кількості щеплень в Італії, Франції та Австралії, де уряди в останні роки вирішили вимагати вакцинації дітей, які мають відвідувати державні освітні заклади [33]. Однак, як зазначає О. Юдін, за рішенням Європейського суду з прав людини у держави головним пріоритетом є захист та охорона життя та здоров'я своїх громадян, отже, в певних випадках ці інтереси мають пріоритет та держава має право в певних випадках забов'язати громадян пройти медичні процедури з метою усунення загрози завдання шкоди здоров'ю населення [34]. 
В Україні останнім часом проведено численні кампанії щодо підвищення обізнаності з питань вакцинації із залученням міжнародних партнерів, однак за даними МОЗ Українив майже два роки в Україні триває спалах кору. Найвищий рівень захворювання зафіксований в регіонах з найнижчими показниками вакцинації (Львівській, ІваноФранківській, Закарпатській, Одеській областях) [35]. Слід зазначити досить низькі показники охоплення вакцинацією серед населення України.

Відповідно до даних ДУ “ЦГЗ MO3 України" від туберкульозу вакциновано лише 33,4 \% дітей до першого року життя, гепатиту В 26,7 \% дітей до 1 року, кір, паротит, краснуха - 28,3 \% однорічних дітей і 30,1 \% - дітей віком 6 років, дифтеpiï, правця вакциновано лише 31,6 \% дітей до року, 32,4 \% дітей віком 18 місяців, 15,9 \% дітей - віком 6 років, 15,5 \% дітей віком 16 років, гемофільної інфекції до одного року - 76,5 \% осіб, одного року - 80,0 \% [36].

Таке ставлення до щеплень вже вилилося в потужний спалах корі в 2017-2019 рр., у разі якщо підходи до комунікативної діяльності в цій галузі не будуть змінені, Україну очікує погіршення епідеміологічної ситуації щодо вакциноконтрольованих інфекцій.

За твердженням Черненко, попри велику кількість комунікаційних кампаній все ще спостерігається низька культура населення, яка призводить до неправильного відношення людей до своїх захворювань, низької медичної грамотність населення, перебільшення значимості народної медицині, розвитку гомеопатії, а від так, масових відмов від вакцинацій [37].

Висновки. Слід зазначити, що комунікативна діяльність публічного адміністрування громадського здоров’я досить складний матеріал для оцінки ефективності, адже не має чітких визначених вимірюваних показників, які можна було б порівняти між різними країнами та моделями. На сьогодні в Україні тільки створюється система громадського здоров’я, вже розбудовано центральний орган ДУ “ЦГЗ МО3 України” та майже завершено формування регіональних ЦГЗ, що стосується публічного управління, можна зазначити, що здебільшого присутня НПА щодо регуляції та координації роботи органів громадського здоров'я, однак що стосується комунікативної діяльності НПА недостатні, а стратегія комунікативної діяльності не сформована. Так, у затвердженій урядом стратегії, або в подальшому не було визначено чітких критеріїв та індикаторів ефективності як комунікативної діяльності, так і в цілому діяльності регіональних ЦГЗ. Здебільшого комунікативна діяльність спрямована або на ситуативну проблему (вакцінація, спалах інфекційних захворювань), або на міжнародні тренди здоров'я (ВІЛ, вживання алкоголю, профілактика онкологічних захворювань) без наявної комунікативної стратегіï регіонального ЦГЗ та без врахування державних та місцевих програм інших установ, що існують паралельно.

Серед проблем, які є визначальними серед питань громадського здоров’я, високу увагу приділено 
розповсюдженню ВІЛ/СНІДу, тютюнопалінню та вакцинації. Однак результати цих інтеракцій важко вважати задовільними (тільки 50 \% ЛЖВ знають про свій діагноз, високий відсоток тих, кого виявлено на пізніх стадіях захворювання, низьке охоплення вакцінацією тощо). Багато комунікативних кампаній проводяться без центральної стратегії та навіть без участі держави (ожиріння, запобігання інсультам, інфарктам тощо).

Таким чином, можна зазначити, що участь держави в створенні та розвитку стратегії комунікативної діяльності громадського здоров'я мінімальна та не відповідає більшості сучасних викликів.

За результатами даного дослідження та враховуючи, що при вивченні наявної наукової літератури не було виявленно дослідженнь щодо комунікативних кампаній, які запам'ятовуються населенням в громадському здоров'ї, перспективними для подальших розвідок є питання та аналіз успішності кампаній, та основних елементів, які відіграли роль в їх запам'ятовуванні, та визначити, чи вплинули вони на зміну поведінки цільової аудиторії, а також комунікативної діяльності громадських організацій в публічному управлінні та адмініструванні громадського здоров'я.

\section{СПИСОК ВИКОРИСТАНИХ ДЖЕРЕЛ}

1. Устав (конституция) всемирной организации здравоохранения // World Health Organization. 2014. [Електронний ресурс]. Режим доступу: https://apps.who.int/gb/bd/
PDF/bd48/basic-documents- 48thedition - ru.pdf?ua=1\#page $=9$. (3вернення 23 жовтня 2020)

2. Сурмин Ю. П. Теория систем и системный анализ. К.: МАУП, 2003. T. 364 .

3. Bernhardt J. M. Communication at the core of effective public health. 2004.

4. Кюкало О. О. Реформування системи охорони здоров'я України у контексті досвіду зарубіжних країн. 2020.

5. Слабкий Г. О., Миронюк В. І., Качала Л. О. Система громадського здоров’я: бачення Всесвітньої організації охорони здоров'я. Основні оперативні функції громадського здоров'я та їх зміст // Україна. Здоров'я нації. 2017. №. 3. С. 24-31.

6. Білинсъка М. М. Прогнозування потенційних впливів політичних рішень на громадське здоров'я //Державне управління: теорія і практика: Електронне наук. фахове вид. 2005. №. 2. C. 155-166.

7. Занфірова Т. А., Радиш Я. Ф. Етикоправові засади регулювання медичної діяльності в україні (за матеріалами літературних джерел) : дис. ... Медичне право України: правовий статус пацієнтів в Україні та його законодавче забезпечення (генезис, розвиток, проблеми і перспективи вдосконалення). Матеріали II Bсеукр. наук.-практ. конф. 17-18 квітня 2008, м. Львів, 2008.

8. Булавінова К. О. Роль комунікаційних стратегій у системі громадського здоров'я України / К. О. Булавінова, О. З. Децик, 3. О. Ціхонь // Україна. Здоров'я нації. 2018. С. 610.

9. Ляшко B. Представлення реформи системи громадського здоров'я. Національний, регіональний та місцевий рівні. [Електронний peсурс]. Режим доступу: http: healthreform.in.ua/wp-content/ 
uploads/2018/03/5_Liashko_Public health.pdf (звернення 19 жовтня 20ㅡㄹ).

10. Яременко C. С. Маркетингова комунікаційна активність промислового підприємства // Бюлетень Міжнар. Нобелівського економічного форумy. 2012. №. 1 (2). С. 441-448.

11. Доронина T. А. Оценка эффективности рекламно-коммуникационной деятельности //Гуманитарные, социально-экономические и общественные науки. 2015. № 10-1.

12. Інформаційний бюлетень. Вип. 1. Система громадського здоров'я [Електронний ресурс] // Міністерство охорони здоров'я України Одеський обласний центр громадського здоров'я. 2020. Режим доступу до ресурсу: https:// healthcenter.od.ua/wp-content/ uploads/2020/09/info-bulleten.pdf

13. Андрущак М. О. и др. Клініко-епідеміологічна характеристика хворих на ВІЛ-інфекцію. 2019.

14. Статистика з ВІЛ/СНІДу. Епідемічна ситуація з ВІЛ-інфекції в Україні станом на 01.04.2019. URL: https:// phc.org.ua/kontrol-zakhvoryuvan/ vilsnid /statistika-z-vilsnidu. 5. Уніфікований клінічний протокол первинної, вторинної (спеціалізованої) та третинної (високоспеціалізованої) медичної допомоги дітям “ВІЛ-інфекція", затвердженим наказом МОЗ Україні від 24.02.2015 р. № 92. URL: https://ips.ligazakon.net/ document/view/MOZ24344?an=1

15. ВІЛ інфекція в Україні: інформ. бюллетень / Державна установа “Центр громадського здоров'я МО3 України”. Київ, 2018. 49.121 с.

16. Шапка $C . M$. ВІЛ-інфекція як одне з найважливіших питань українського суспільства. С. 181.

17. Горпинич $A$. Ставлення українського суспільства до проблеми ВІЛ/ СНІДу // Соціальна робота: ста- новлення, перспективи, розвиток. C. 62.

18. Огоренко В. В., Гненна О. М. Особливості ставлення студентів-медиків до людей, які живуть з ВІЛінфекцією // Вісн. проблем біології і медицини. 2019. Т. 2. C. 168-171.

19. Mean BMI [Електронний ресурс] // WHO. The global health observatory. 2020. Режим доступу: https://www. who.int/data/gho/data/indicators / indicator-details/GHO/mean-bmi(kg-m-)- (crude-estimate)

20. МОЗ України представило рекомендації зі здорового харчування [Електронний ресурс] // Офіційний сайт МОЗ України. 2017. Режим доступу: https://moz.gov.ua/article/ news/moz-ukraini-predstavilorekomendacii-zi-zdorovogoharchuvannja

21. Заболотна I. Е., Ященко Л. В. Obesity and overweight among children, diagnostic criteria and statistics of prevalence // Клінічна та профілактична медицина. 2019. Т. 2. №. 8. С. 36-46.

22. Помогайбо К. Г. Медико-соціальне обгрунтування моделі управління якістю життя дітей 3 ожирінням : дис. 2019.

23. Lebedynets P., Lebedynets D., Lebedynets $V$. Atrial fibrillation, cardioembolism and heart-brain interactions // Journal of the Neurological Sciences. 2019. Т. 405. C. 111.

24. Догоспітальна медична допомога при гострих порушеннях мозкового кровообігу. Перші результати реформи на прикладі Одеської області [Електронний ресурс] / [T. Muratova, D. Khramtsov, O. Stoyanov та ін.] // Вісн. соціальної гігієни та організації охорони здоров’я України. 2020. Режим доступу:https://doi.org/10.11603/16812786.2020.1.11211 
25. У 2020 році НСЗУ оплатить лікування гострого мозкового інсульту за підвищеним тарифом [Електронний ресурс]. 2020. Режим доступу: https://nszu.gov.ua/ novini/u- 2020- roci-nszu-oplatitlikuvannya- gostrogo-mozkovogoinsul-103

26. Гузій О. В. Академія інсульту: сучасні методи боротьби з інсультом в Україні та світі [Електронний ресурс] // Український медичний часопис. 2019. Режим доступу: https:// www.umj.com.ua/article/164192/ akademiya-insultu-suchasnimetodi-borotbi-z-insultom-vukrayini-ta-sviti

27. Кошеля I. I. Епідеміологія інфаркту міокарда в Україні // Україна. Здоров’я нації. 2020. Т. 2. № 3.

28. Які послуги, обстеження та аналізи для профілактики та лікування серцево-судинних захворювань можна отримати безоплатно? [Електронний ресурс] // Офіційний сайт Національної служби здоров'я України. 2019. Режим доступу: https:// nszu.gov.ua/novini/yaki-poslugiobstezhennya-ta-analizi-dlyaprofilaktiki-ta-li-77

29. Сокол К. Гіпертонічна хвороба, інфаркт міокарда. Соціально-медичне дослідження / К. Сокол, А. Шульгай. Тернопіль : Лілея, 2011. $160 \mathrm{c}$.

30. Рудень В. В., Ковальська I. М. Аналіз і прогноз показників смертності 3 причини гострого інфаркту міокарда| I. 21| серед населення в Україні // Україна. Здоров’я нації. 2019. №. 1. С. $131-139$.

31. Звіт ГО “ЖИТТЯ” [Електронний ресурс]. 2019. Режим доступу: https://center-life.org/wp-content/ uploads/2020/06/Publichnyy-zvit2019-r..pdf

32. Blewer A. L. et al. Impact of bystander - focused public health interven- tions on cardiopulmonary resuscitation and survival: a cohort study // The Lancet Public Health. 2020. T. 5. №. 8. C. 428-436.

33. De Ambrogi M. Why do parents not want to vaccinate their children? // The Lancet Infectious Diseases. 2018. T. 18. № 8. C. 844.

34. Юдін О. Вакцинація: до та після рішення Верховного Суду //Український медичний часопис. 2019. №. 3 (1). C. 37-38.

35. ВООЗ: Відмова від вакцинації є глобальною загрозою людству [Електронний ресурс] // Офіційний сайт MO3 України. 2019. Режим доступу: https://moz.gov.ua/article/news/ vooz-vidmova-vid-vakcinacii-eglobalnoju-zagrozoju-ljudstvu

36. Центр громадського здоров’я МОЗ України “Загальні дані щодо охоплення щепленнями по Україні” [Електронний ресурс]. Peжим доступу: https://phc.org.ua/ kontrolzakhvoryuvan/imunizaciya/ okhoplennya-scheplennyami

37. Черненко I. I., Самохін Д. С. Проблеми соціальної роботи в Україні : дис. 2019 .

\section{REFERENCES}

1. Ustav (konstitutsiya) vsemirnoy organizatsiizdravookhraneniya [Charter (constitution) of the world health organization]. (2014). apps.who.int. Retrieved from https://apps.who.int/ $\mathrm{gb} / \mathrm{bd} / \mathrm{PDF} / \mathrm{bd} 48 / \mathrm{basic}$-documents48th-edition-ru.pdf?ua $=1 \#$ page $=9$ [in Russian].

2. Surmin Yu. P. (2003). Teoriya sistem $i$ sistemnyy analiz [Theory of systems and system analysis]. Kyiv: MAUP [in Russian].

3. Bernhardt J. M. (2004). Communication at the core of effective public health. Am J Public Health, 94(12), 2051-2053 [in English]. 
4. Kiukalo O. O. (2020). Reformuvannia systemy okhorony zdorovia Ukrainy u konteksti dosvidu zarubizhnykh krain [Reforming the health care system of Ukraine in the context of the experience of foreign countries]. Extended abstract of master's thesis. Mykolaiv: ChNU im. Petra Mohyly [in Ukrainian].

5. Slabkyi H. O., Myroniuk V. I., Kachala L. O. (2017). Systema hromadskoho zdorovia: bachennia Vsesvitnoi orhanizatsii okhorony zdorovia. Osnovni operatyvni funktsii hromadskoho zdorovia ta yikh zmist [Public health system: vision of the World Health Organization. Basic operational functions of public health and their content]. Ukraina. Zdorovia natsii Ukraine. The health of the nation, 3, 24-31 [in Ukrainian].

6. Bilynska M. M. (2005). Prohnozuvannia potentsiinykh vplyviv politychnykh rishen na hromadske zdorovia [Forecasting of potential influences of political decisions on public health]. Derzhavne upravlinnia: teoriia i praktyka - Public administration: theory and practice, 2, 155-166 [in Ukrainian].

7. Zanfirova A., Radysh Ya. F. (2008). Etyko pravovi zasady rehuliuvannia medychnoi diialnosti v Ukraini (za materialamy literaturnykh dzherel) [Ethical and legal principles of regulation of medical activity in Ukraine (according to the materials of literary sources)]. Medychne pravo Ukrainy: pravovyi status patsiientiv v Ukraini ta yoho zakonodavche zabezpechennia (henezys, rozoytok, problemy $i$ perspektyoy vdoskonalennia) - Medical law of Ukraine: legal status of patients in Ukraine and its legislative support (genesis, development, problems and prospects for improvement): Proceedings of the II All-Ukrainian scientificpractical conference. (p. 124-128). Lviv [in Ukrainian].
8. Bulavinova K. O. Detsyk O. Z., Tsikhon Z. O. (2018). Rol komunikatsiinykh stratehii u systemi hromadskoho zdorovia Ukrainy [The role of communication strategies in the system of public health of Ukraine]. Ukraina. Zdorovia natsii - Ukraine. The health of the nation, 3, 6-10 [in Ukrainian].

9. Liashko V. (2018). Predstavlennia reformy systemy hromadskoho zdorovia. Natsionalnyi, rehionalnyi ta mistsevyi rivni [Presentation of public health system reform. National, regional and local levels]. healthreform.in.ua. Retrieved from http:// healthreform.in.ua/wp-content/uploads/2018/03/5_Liashko_Public_ health.pdf [in Ukrainian].

10. Yaremenko S. S. (2012). Marketynhova komunikatsiina aktyvnist promyslovoho pidpryiemstva [Marketing communication activity of an industrial enterprise]. Biuleten Mizhnarodnoho Nobelivskoho ekonomichnoho forumu - Bulletin of the International Nobel Economic Forum, 1(2), 441-448 [in Ukrainian].

11. Doronina T. A. (2015). Otsenka effektivnosti reklamno-kommunikatsionnoy deyatelnosti [Evaluation of the effectiveness of advertising and communication activities]. Gumanitarnye, sotsialno-ekonomicheskie $i$ obshchestvennye nauki - Humanities, socio-economic and social sciences, 10, 73-75 [in Russian].

12. Informatsiinyi biuleten. Vyp. 1. Systema hromadskoho zdorovia [Newsletter. Issue 1. Public Health System]. (2020). Odesa. Retrieved from https://healthcenter.od.ua/wp-content/ uploads/2020/09/info-bulleten.pdf [in Ukrainian].

13. Andrushchak M., Moskaliuk V., Balaniuk I., \& Rudan I. (2019). Klinikoepidemiolohichna kharakterystyka khvorykh na VIL-infektsiiu [Clinical 
and epidemiological characteristics of patients with HIV-infection]. Aktualni problemy suchasnoi medytsyny: Visnyk Ukrainskoi medychnoi stomatolohichnoi akademii - Actual problems of modern medicine: Bulletin of Ukrainian Medical Stomatological Academy, 19(3), 3-6 [in Ukrainian].

14. Statystyka z VIL/SNIDu. Epidemichna sytuatsiia z VIL-infektsii v Ukraini stanom na 01.04.2019b [HIV/AIDS statistics. The epidemic situation with HIV infection in Ukraine as of April 1, 2019]. (n.d.). phc.org.ua. Retrieved from https://phc.org.ua/kontrolzakhvoryuvan/vilsnid/statistika-zvilsnidu\#: :text=Станом\%20на\% 20 $01.04 .2019 \% 20 y$,» \%20(111\%2C3) [in Ukrainian].

15. VIL infektsiia v Ukraini [HIV infection in Ukraine]. (2018). Kyiv: Derzhavna ustanova "Tsentr hromadskoho zdorovia MOZ Ukrainy" [in Ukrainian].

16. Shapka Ye. M. (2020). VIL-infektsiia yak odne $\mathrm{z}$ naivazhlyvishykh pytan ukrainskoho suspilstva [HIV infection as one of the most important issues of Ukrainian society]. Sotsiolohichni Dyskursy - Sociological discourses : Proceedings of the III All-Ukrainian Scientific Conference of young scientists. (p. 181-184). Dnipro: Vydavnycho-polihrafichnyi dim "Format A+" [in Ukrainian].

17. Horpynych A. (2020). Stavlennia ukrainskoho suspilstva do problemy VIL/SNIDu [Attitude of Ukrainian society to the problem of HIV/AIDS]. Sotsialna robota: stanozlennia, perspektyoy, rozoytok - Sotsialna robota: stanovlennia, perspektyvy, rozoytok Social Work: Formation, Prospects, Development: Proceedings of the V International scientific-practical conference. (p. 62-67). Lviv: LDU BZhD [in Ukrainian].

18. Ohorenko V. V., Hnenna O. M. (2019). Osoblyvosti stavlennia stu- dentiv-medykiv do liudei, yaki zhyvut z VIL-infektsiieiu [Features of the attitude of medical students to people living with HIV infection]. Visnyk problem biolohii i medytsyny - Bulletin of problems biology and medicine, 2 , 168-171 [in Ukrainian].

19. Mean BMI $\left(\mathrm{kg} / \mathrm{m}^{2}\right)$ (crude estimate). (n.d.). wrww.who.int. Retrieved from https://www.who.int/data/gho/ data/indicators/indicator-details/ GHO/mean-bmi-(kg-m-)-(crude-estimate) [in English].

20. MOZ Ukrainy predstavylo rekomendatsii zi zdorovoho kharchuvannia [The Ministry of Health of Ukraine presented recommendations for healthy eating]. (2017). moz.gov.ua. Retrieved from https://moz.gov.ua/ article/news/moz-ukraini-predstavilo-rekomendacii-zi-zdorovogo-harchuvannja [in Ukrainian].

21. Zabolotna I. E., Yashchenko L. V. (2019). Obesity and overweight among children, diagnostic criteria and statistics of prevalence. Klinichna ta profilaktychna medytsyna - Clinical and preventive medicine, 2(8), 3646 [in Ukrainian].

22. Pomohaibo K. H. (2019). Medykosotsialne obgruntuvannia modeli upravlinnia yakistiu zhyttia ditei $\mathrm{z}$ ozhyrinniam [Medico-social substantiation of the model of quality management of children's lives with obesity]. Extended abstract of candidate's thesis. Kharkiv [in Ukrainian].

23. Lebedynets P., Lebedynets D., Lebedynets V. (2019). Atrial fibrillation, cardioembolism and heart-brain interactions. Journal of the Neurological Sciences, 405, 111 [in English].

24. Muratova T., Khramtsov D., Stoyanov O., et al. (2020). Dohospitalna medychna dopomoha pry hostrykh porushenniakh mozkovoho krovoobihu. pershi rezultaty reformy na prykladi 
Odeskoi oblasti [Prehospital medical care for acute cerebrovascular disorders. the first results of the reform on the example of Odessa region]. Visnyk sotsialnoi hihiieny ta orhanizatsii okhorony zdorovia Ukrainy - Bulletin of Social Hygiene and Health Protection Organization of Ukraine, 1, 75-87. https://doi.org/10.11603/16812786.2020.1.11211 [in Ukrainian].

25. U 2020 rotsi NSZU oplatyt likuvannia hostroho mozkovoho insultu za pidvyshchenym taryfom [In 2020, the National Health Insurance Fund will pay for the treatment of acute stroke at a higher rate]. (2020). nszu.gov. ua. Retrieved from https://nszu.gov. ua/novini/u-2020-roci-nszu-oplatitlikuvannya-gostrogo-mozkovogo-insul-103 [in Ukrainian].

26. Huzii O. V. (2019). Akademiia insultu: suchasni metody borotby $\mathrm{z}$ insultom $\mathrm{v}$ Ukraini ta sviti [Academy of stroke: modern methods of combating stroke in Ukraine and the world]. Ukrainskyi medychnyi chasopys - Ukrainian medical journal, 6(1), 15-17. Retrieved from http://nbuv.gov.ua/ UJRN/UMCh_2019_6\%281\%29_7 [in Ukrainian].

27. Koshelia I. I. (2020). Epidemiolohiia infarktu miokarda v Ukraini [Epidemiology of myocardial infarction in Ukraine]. Ukraina. Zdorovia natsii Ukraine. The health of the nation, 2(3), 63-68 [in Ukrainian].

28. Yaki posluhy, obstezhennia ta analizy dlia profilaktyky ta likuvannia sertsevo-sudynnykh zakhvoriuvan mozhna otrymaty bezoplatno? [What services, examinations and tests for the prevention and treatment of cardiovascular disease can be obtained free of charge?]. (2019). nszu.gov.ua. Retrieved from https://nszu.gov.ua/ novini/yaki-poslugi-obstezhennyata-analizi-dlya-profilaktiki-ta-li-77 [in Ukrainian].
29. Sokol K., Shulhai A. (2011). Hipertonichna khvoroba, infarkt miokarda. Sotsialno-medychne doslidzhennia [Hypertension, myocardial infarction. Socio-medical research]. Ternopil: Lileia [in Ukrainian].

30. Ruden V. V., Kovalska I. M. (2019). Analiz i prohnoz pokaznykiv smertnosti z prychyny hostroho infarktu miokarda| I. 21| sered naselennia v Ukraini [Analysis and prognosis of mortality due to acute myocardial infarction|I. 21 among the population in Ukraine]. Ukraina. Zdorovia natsii Ukraine. The health of the nation, 1 , 131-139 [in Ukrainian].

31. Zvit HO "ZhYTTIa" [Report of the Public Organization "LIFE"]. (2019). center-life.org. Retrieved from https://center-life.org/wpcontent/uploads/2020/06/Publichnyy-zvit-2019-r..pdf [in Ukrainian].

32. Blewer A. L., et al. (2020). Impact of bystander - focused public health interventions on cardiopulmonary resuscitation and survival: a cohort study. The Lancet Public Health, 5(8), e428-e436 [in English].

33. De Ambrogi M. (2018). Why do parents not want to vaccinate their children? The Lancet Infectious Diseases, 18(8), 844 [in English].

34. Yudin O. (2019). Vaktsynatsiia: do ta pislia rishennia Verkhovnoho Sudu [Vaccination: before and after the decision of the Supreme Court]. Ukrainskyi medychnyi chasopys - Ukrainian Medical Journal, 3(1), 37-38 [in Ukrainian].

35. VOOZ: Vidmova vid vaktsynatsii ye hlobalnoiu zahrozoiu liudstvu [WHO: Refusal of vaccination is a global threat to humanity]. (2019). moz.gov. ua. Retrieved from https://moz.gov. ua/article/news/vooz-vidmova-vidvakcinacii-e-globalnoju-zagrozojuljudstvu [in Ukrainian]. 
36. Tsentr hromadskoho zdorovia MOZ Ukrainy "Zahalni dani shchodo okhoplennia shcheplenniamy po Ukraini" [Public Health Center of the Ministry of Health of Ukraine "General data on vaccination coverage in Ukraine"]. (n.d.). phc.org.ua. Retrieved from https://phc.org.ua/kontrolzakhvoryuvan / i mun i z a c i ya / okhoplennya-scheplennyami[inUkrainian].
37. Chernenko I. I., Samokhin D. S. (2019). Problemy sotsialnoi roboty v Ukraini [Problems of social work in Ukraine]. Nadbannia suchasnoi epidemiolohii ta biostatystyky yak zaporuka pokrashchannia hromadskoho zdorovia v Ukraini - Acquisition of modern epidemiology and biostatistics as a guarantee of improving public health in Ukraine: Proceedings of the scientific-practical conference. (p. 58-60). Kharkiv [in Ukrainian]. 